\section{A CASE OF SEVERE ECTHYMA FROM WHICH THE DIPHTHERIA BACILLUS HAS BEEN ISOLATED.}

BY A. EDDOWES, M.D. EDIN., M.R.C.P. LOND., PHYSICTAN TO ST. JOHN'S HOSPITAL FOR DISEASES OF THE SKIN, LEICESTER-SQUARE, LONDON, W.C.;

AND

J. G. HARE,

PATHologist aND BACTERIOLOGIST To sT. JOHN's HOSPITAI FOR DISEASES OF THE SKIN.

The patient, a girl, aged 11 jears, was first seen on Jan. 2nd, 1907. The case was recognised as one of severe type. The contents of a bulla were examined bacteriologically but no streptococcus was found on this occasion. Carbolic lotion and mercurial ointment were prescribed and the patient was told to come again in a week's time. On the 9th the patient showed numerous bullæ on both arms, hands, and lips. Upon the left anterior pillar of the fauces could be seen traces of a ruptured and healing vesicle. There was no false membrane; there was no complaint of sore-throat, thongh there had been some soreness felt in the throat three days previously. As the child appeared ill and the case was probably being mismanaged at home she was admitted to St. John's Hospital for Diseases of the Skin as an in-patient, but before admission the case was again sent for a careful bacteriological examination. Some uneasiness was felt on account of the patient's general symptoms, but improvement took place at once after she had passed into the hands of the nurses and had all the sores thoroughly dressed with antiseptics; in fact, in 24 hours the patient was quite out of danger and made an nninterrupted recovery. Careful inquiry failed to elicit any plausible origin of the infection. Incidentally it may be mentioned that the child's father is the subject of myxoedema. The child's skin, however, is naturally normal. In May the child was seen and again later and there had not been any relapse.

\section{Bacteriological Report.}

1. A small bulla on the right hand $w$ as carefully sterilised first with 1 in 20 carbolic acid solution and afterwards with ether and then a sterile platinum needle was inserted and an agar slope inoculation was made with the fluid. From this a growth of staphyloeoccus hours later. On plating these two organisms were found to be in pure cultuer.

2. The surface of the bulla was excisf $d$ and a gentle impression was made on a microscopic slide from the "ceiling" or under surface of

FIG. 1.

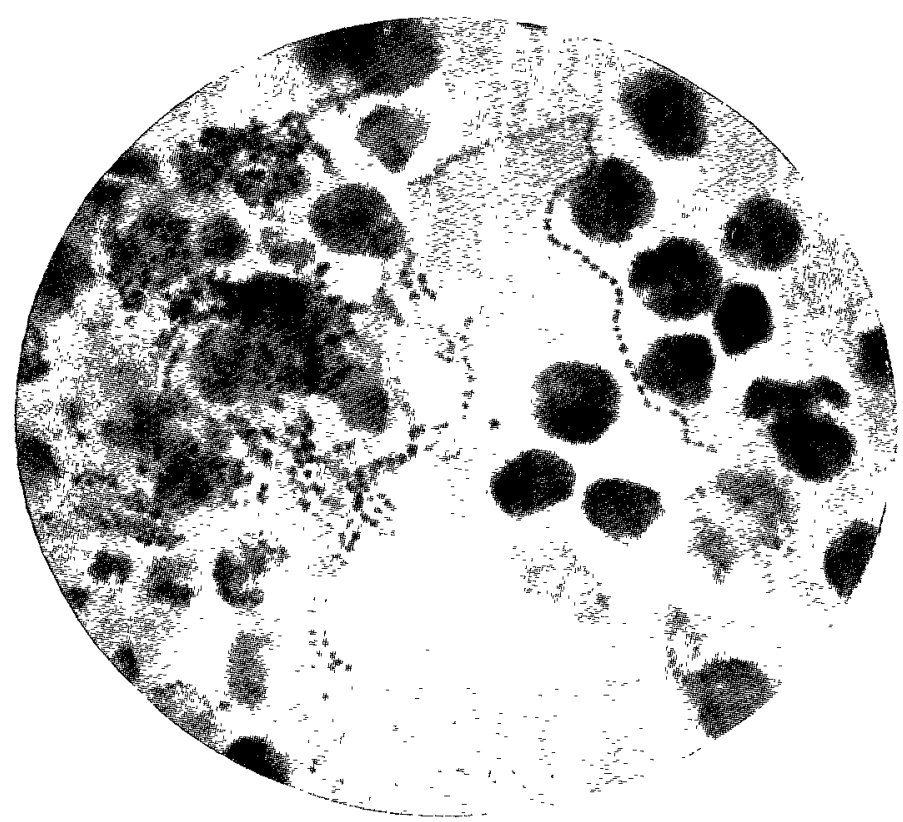

Streptococci. Impression from bulla.

the roof of the bulla. This was also scraped with a sterile platinum loop and an agar tube inoculated. The slide was stained with Loeffer' methylene blue and on examination it showed long-chained streptncocci, apparently in pure culture (Fig. 1). From the inoculated tube a growth of streptococeus vas obtained in pure cultivation. This was again subcultured in broth and a characteristic growth was obtained. 3. A small unbroker pustule on the left hand was then examined. A platinum needle was inserted and two agar-agar tubes inosulated. The growth obtained 18 hours later was typical staphylococcus aureusand albus but together with these, and in separate colonies, there was whin translucent growth. which on smears being made and stained with methylene blue showed a bipolar staining bacillus. The bacilli in parts were only faintly stained; the grouping arrangement was parallel; there were many club-shaped forms, also V-shaped splitting (Fig. 2); The organism reacted to Neisser's stain and it also stained by Gram's method. From this colony two blood-serum tubes were inoculated and the bacillus was obtained in pure culture.

On Jan. 17th, 1907, a 300 gramme guinea-pig was inoculated per peritoneum with two cubic centimetres of serum suspension of this culture. 27 hours later the guinea-pig was dead. On the 19th a postmortem examination was made, revealing extensive cedema of the peritoneum and hæmorrhages and enlargement of the spleen. Cuitures were made from the seat of inoculation and from the heart on blood serum and a growth of this organism was obtained 18 hours the streptococcus. The organism appears to be non-pathogenic,

$$
\text { FI } \div \text {. } 2 .
$$

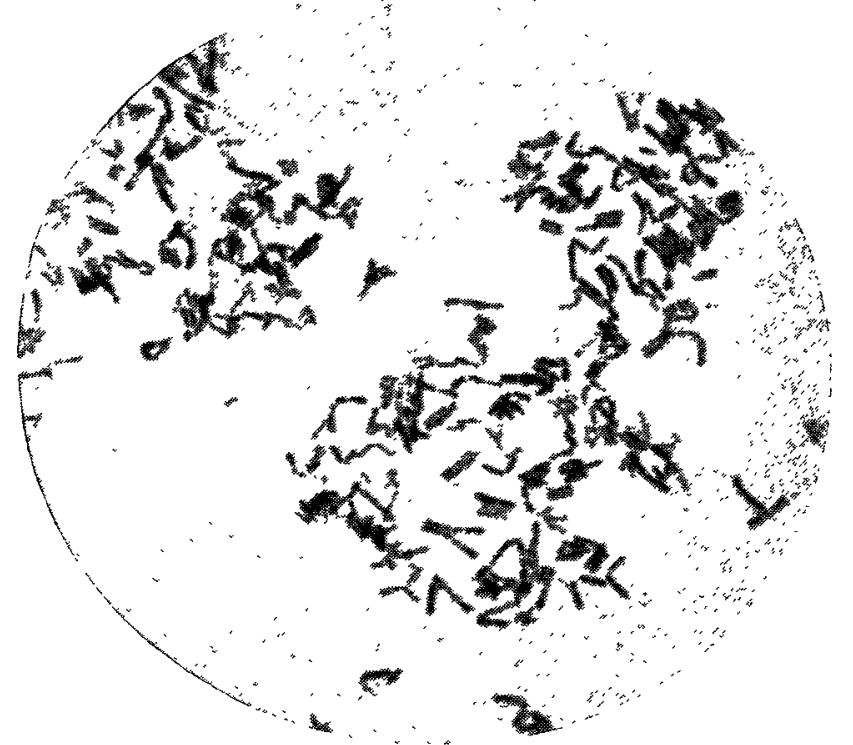

Klebs-Löffler bacillus from pustule on the hand.

up to the time of writing the guinea-pig is still alive. A third guineapig, however, being inoculated with the bipolar staining bacillus plus the staphylococcus dien 72 hours later, and both organisms have been recovered in pure cult ure. Furtber inoculations were then made. A recovered in pure cult ure. Furtber inoculations were then made. A guinea-pig was inocul ited with $0 \cdot 75$ cubic centimetre of the organisms
obtained in pure culture from the guinea-pig. Deat h oceurred 48 hours obtained in pure culture from the guinea-pig. Death occurred 48 hours later, while one inoculated with 12 cubic centimetres

All the lesions cleared up rapidly under local antisepti : treatment" All the lesions cleared up rapidly under local ant

In a second case I am indebted to Dr. Alan B. Slater for carrying out the treatment at the patient's own home.

** The second case referred to by Dr. Eddowes appeared in THE LANCET of Jan. 4th. No mention was then made by Dr. Slater that he was associated with Dr. Eddowes in the case, while we were unaware that the patient came under treatment at the St. John's Hospital for Diseases of the Skin and not at the Farringdon General Dispensary, where Dr. Slater is physician to the Skin Department. Dr. Slater, whose attention we have drawn to the matter, says that the case was handed over to him by Dr. Hargreaves, physician to the St. John's Hospital, whose assistant he was, with full permission for publication.-ED. L.

The Royal Sanitary Institute.-The List of Honorary Fellows, Members, and Associates elected in January, 1908, includes the following names : Professor Dott. Cavaliere Giuseppe Badaloni, of Rome; Professor Leo Burgerstein, of Viezna; Professor G. W. Chlopine, of St. Petersburg ; Professor H. Griesbach, of Mulbausen ; Professor Kirchner, of Berlin ; Dr. Albert Mathieu, of Paris ; Professor M. Mishima, M D., Principal Medical Officer, Ministry of Education, Tokio ; Dr. Luigi Pagliani, Professor of Hygiene, University of Turin ; Professor Alb. Palmberg, of Helsingfors; iir H. H. Pinching, K.C.M.G., late Director-General, Public Health Department, Cairo, Egypt ; and Dr. Marc Armand Ruffer, O.M.G. 